\title{
Effect of Date Fruits Quantity on the Numbers of Red Palm Weevil, Rhynchophorus ferrugineus (Olivier), Captured in Aggregation Pheromone Traps
}

\author{
Ahmad Al Saoud'and Aziz Ajlan² \\ ${ }^{1}$ Bani Yas Agriculture Research and Experiments Station, General Agricultural Directorate, \\ Abu Dhabi, United Arab Emirates \\ ${ }^{2}$ Department of Arid Land Agriculture, College of Agricultural and Food Sciences, King Faisal \\ University, PO Box 55009, Hofuf, Alhasa 31982, Saudi Arabia
}

\begin{abstract}
ASTRACT
Red palm weevil (RPW), Rhynchophorus ferrugineus (Olivier) (Coleoptera: Curculionidae), is controlled using Integrated Pest Management (IPM), which depends on the aggregation pheromone traps. Field trials were conducted on 3 date palm plantations in Al Rahba, Abu Dhabi, UAE, from June 1, 2010 to May 31, 2011 containing 6 replications and 3 treatments $(350 \mathrm{~g}, 450 \mathrm{~g}$ and $550 \mathrm{~g}$ of dates). Result of 18 traps indicated that the highest catch of adults RPW was in March and April 2011 with an average of 93.3 and 70.8 weevils/trap, respectively while the lowest catch was in September 2010 with an average of 5.5 weevils/Trap. The total number of captured weevils was 6147 of which 2067 were males and 4080 were females with sex ratio (1:2). The data presented that there are significant differences between the 3 treatments. The traps baited with $450 \mathrm{~g}$ of dates recorded the highest catch with 2230 weevils, followed by the treatment $350 \mathrm{~g}$ of dates with 2037 weevils while the treatment $550 \mathrm{~g}$ of dates, was the lowest with 1880 weevils. Consequence of aggregation pheromone traps of RPW with $450 \mathrm{~g}$ of dates as baits using black bucket traps. More investigations are needed to improve the effectiveness of this technique.
\end{abstract}

Keywords: Rhynchophorus ferrugineus, pheromone traps, bait, date fruit quantity.

\section{INTORODUCTION}

The date palm (Phoenix dactylifera L.) is considered symbol of life in the desert, because it tolerates high temperatures, drought and salinity more than many other fruit crop species. One of the oldest relationships which man has had with a tree has been with date palms, which have been cultivated since ancient times (Zohary and Hopf, 2012).

Several insects infest date palm trees, of which the red palm weevil (RPW), Rhynchophorus ferrugineus (Olivier) (Coleoptera: Curculionidae), is one of the most important and damaging pests, being major threat to date palm trees all over the world (Abraham et al., 1998; Faleiro, 2006; Frohlich and Rodewald, 1970; Morphy and Briscoe, 1999; Oehlschlager, 1995; Poorjavad et al., 2009; Vidyasagar et al., 2000a). The red palm weevil is commonly well hidden, and many regional infestations have only recently been recognized (Al-Saoud, 2007; Faleiro and Satarkar, 2003), making the red palm weevil a pest of major economic importance in all Persian Gulf Countries (Abraham et al., 1998; Abraham et al., 2000; Abraham et al., 2002; Al-Saoud et al., 2010; Bokhari and Abuzuhairah, 1992).

Red palm weevil larvae penetrate trunk tissue after hatching and begin digging passages in different directions and consuming large quantities of plant tissue (Faleiro, 2004; Hallett et al.,1999). Because both larvae and adults prefer to remain and multiply in the infested trunk, it is difficult to detect early infestation of RPW while late infestation can be seen when the trunk broken due to wind or due to other factor (Abraham et al., 2001; Al-Saoud, 2009a; AlSaoud, 2010a; Faleiro, 2006; Faleiro et al., 1998).

Several factors have enabled the red palm weevil to spread widely in the Persian Gulf region: (1) The pest presented during the entire year (Abraham et al., 1999; Al-Saoud, 2009a; Al-Saoud, 2010b; Faleiro and Ragnakar, 2001; Vidyasagar et al., 2000b). (2) Catch of weevils is predominantly female (Abraham et al., 1999; Al-Saoud, 2009b; Al-Saoud, 2011a; Faleiro and Ragnekar, 2000). (3) Adults are strong flyers, with a high dispersal capacity; (Al-Saoud, 2010b). (4) Good environmental conditions for the 
pest prevail in the Persian Gulf region (Al-Saoud, 2010b; Faleiro, 2006). (5) Their host (date palm trees) are available all year; (Al-Saoud, 2009a; Faleiro, 2006) and (6) All life stages (egg, larvae, pupa and adult) are spent inside the infested trunks (Ajlan, 2009; Al-Saoud, 2009a; Ferry and Gomez, 2002; Kaakeh, 2006).

The red palm weevil is difficult to control in the early stages of attack because it is an internal tissue borer (Abraham et al., 1998). Initial attempts to control red palm weevil with insecticides were not successful (Bokhari and Abozuhairah, 1992) and since 1994 an Integrated Pest Management (IPM) strategy, modeled on the lines of tackling the same pest on coconut in India (Abbas et al., 2006; Abraham et al., 1998; Faleiro et al., 1998; Vidyasagar et al., 2000b) has been implemented in the Saudi Arabia. So far, this IPM strategy has successfully suppressed the pest in Saudi Arabia date plantations (Abozuhaira et al., 1996; Abraham et al., 1999).

This IPM program is based on the use of aggregation pheromone traps that attract both male and female weevils (Abraham et al., 1998; Abraham et al., 2001; Al-Saoud, 2004; Al-Saoud et al., 2010; Faleiro et al., 1998; Oehlschlager, 1998; Oehlschlager et al., 2002;). Pheromone trapping of red palm weevil an ecologically safe and environmentally friendly tool in the IPM strategy currently adopted worldwide for red palm weevil management in date palm plantations and one that can be implemented on large scale either by the state or by farmers on a collective basis.

Pheromone trap effectiveness is influenced by many factors, including color (Abdalah and Al-Khatri, 2005; Ajlan and Abdulsalam, 2000; Al-Saoud et al., 2010; Hallett et al., 1999) pheromone type (Faleiro and Chellapan, 1999; Faleiro and Satarkar, 2003), trap contents (Al-Saoud, 2007; Al-Saoud, 2009b), food bait (Al-Saoud, 2011a;Faleiro, 2004; Nair et al., 2000), and trap location Al-Saoud, 2011b; Faleiro, 2004; Hallett et al, 1999.

Date fruits proved to be better than banana or sugarcane as bait for pheromone traps (Al-Saoud, 2011a), and the quantity of date fruit per trap also appeared to have an impact on the effectiveness of the traps (Abdalah and Al-Khatri, 2005; Al-Saoud, 2009b).

The objective of this study was to evaluate the impact of date fruit quantity on the effectiveness of pheromone traps in date palm plantations in $\mathrm{Al}$ Rahba, Abu Dhabi, UAE.

\section{MATERIAL AND METHODS}

Study sites: The experiment was conducted in 3 date palm plantations infested with RPW in Al-Rahba, Abu Dhabi $\left(24^{\circ} 28^{\prime} 0^{\prime \prime} \mathrm{N}, 54^{\circ} 22^{\prime} 0^{\prime \prime} \mathrm{E}\right)$, UAE from June 1, 2010 to May 31, 2011. Each farm has at least 140 date palm trees, from 6-30 years old.

Traps and treatments: Pheromone traps were fabricated using a 10 liter black bucket, the color of which had been recommended as superior to yellow or white traps and recommended by (Al-Saoud, 2012). Each trap had four rectangular windows $(3 \times 7$ $\mathrm{cm})$ cut equidistantly locations around the upper rim of the bucket. The distance between each window and the bottom of the bucket was $16 \mathrm{~cm}$. The bucket was covered with a lid that had four windows matching the ones on its sides. The outer surface of the bucket was roughened with small projection (1-2 $\mathrm{mm}$ ) to help the weevils climb to the trap and enter. The upper surface of the lid had a small handle to ease opening the trap and the underside of the lid had a small knob to which a wire was fixed to hold the pheromone and ethyl acetate (EA) dispensers. Each trap contained the following materials: (i) dispenser of the RPW male aggregation pheromone (Ferrolure $^{\mathrm{TM}}$ ) containing $700 \mathrm{mg}$ of the active ingredient (4-Methyl-5-Nonanol 90\% + 4-Methyl-5Nonanone $10 \%$ ) at $95 \%$ purity, (ii) Ethyl acetate dispenser (Weevil Mangnet ${ }^{\mathrm{TM}}$ ) containing $40 \mathrm{ml}$ of the active ingredient of EA at $98 \%$ purity, (iii) 4- 5 liter of water, creating a water level inside the trap of 4-5 $\mathrm{cm}$ below the windows. There were three treatments, as follows: 1) T1: Trap + 350gof dates, (2) T2: Trap $+450 \mathrm{~g}$ of dates and (3) T3: Trap $+550 \mathrm{~g}$ of dates (Totals 18 traps). Water in the traps was replenished as needed to maintain sufficient moisture. Dates were changed once a month, and a new pheromone lure added every 45 days during the cool and cold session (October-April), and every month during warmer and hot session (May-September) to sustain trapping efficiency. Traps were set on the ground beside the trunk. The number of weevils captured (male and female) was recorded weekly, at which time the trap was shaken well to prevent the growth of any fungi or mold. All traps were shifted weekly to its neighbor site to avoid a location effect due to the aggregation, in rotary manner.

Experimental design and trap installation: The experimental design was a randomized complete block design with three treatments and six replicates. Dates were had been soaked in water for24 hours then had the water squeeze out of them before being used in traps. 
A total of 18 traps were used from June 1, 2010 to May 31, 2011. The distance between traps was about $50 \mathrm{~m}$ and each trap was placed on the ground near the trunk of a palm tree. The traps were surveyed weekly, and the number of males, females and total weevils recorded for each trap and replicate. Numbers were tallied weekly, monthly, and cumulatively throughout the experimental period. A monthly record of the number of weevils trapped in each of the 18 pheromone traps was maintained throughout the study time and the activity of RPW during the months of the year.

Statistical analysis: The data were analyzed using ANOVA and the means were compared using the Least Significant Difference (LSD 5\%) test.

\section{RESULTS AND DISCUSSION}

Activity of RPW in Al-Rahba throughout June 2010 to May 2011: Our traps caught RPW during the study time, although varied from month to month (Table.1). Average monthly catches per trap for the 3 combined treatments were 22.1, 21.7, 10.9, 5.5, 9.3, $11.4, \quad 7.7, \quad 24.4, \quad 39.9, \quad 93.3,70.8$ and 24.6 weevils/trap/month from June 1, 2010 to May 31, 2011, respectively. The highest monthly per trap catch was in March and April 2011 with an average of 93.3 and 70.8 weevils, respectively while the lowest was in September 2010 with an average of only 5.5 weevils caught.

Sex Ratio of RPW: Of the 6,147 total weevils caught, 2,067 were males and 4,080 were females, establishing a sex ratio (males: females) of $1: 2$ (Table 1 ). The sex ratio changed from month to month during the study period, being $1: 2.5,1: 1.8,1: 3.2,1$. 2.5, 1: 3.2, 1:2.4, 1: 1.8, 1:2.1, 1:2, 1:2.1, 1:1.7, 1: 1.4 , respectively.

Table 1. Number of RPW in 18 traps (Males, Females, Totals and Sex Ratio) in Al-Rahba, Abu Dhabi, UAE during June 1, 2010- May 31, 2011

\begin{tabular}{|l|l|l|l|l|l|l|l|l|l|l|l|l|l|}
\hline & $\begin{array}{l}\text { June } \\
2010\end{array}$ & July & Aug. & Sep. & Oct. & Nov. & Dec. & $\begin{array}{l}\text { Jan. } \\
2011\end{array}$ & Feb. & March & April & May & $\begin{array}{l}\text { Total } \\
\text { means/year }\end{array}$ \\
\hline Male & 115 & 140 & 46 & 28 & 40 & 61 & 49 & 142 & 243 & 545 & 474 & 184 & 2067 \\
\hline $\begin{array}{l}{ }^{*} \text { Mean } \\
\text { males }\end{array}$ & 6.4 & 7.8 & 2.6 & 1.6 & 2.2 & 3.4 & 2.7 & 7.9 & 13.5 & 30.3 & 26.3 & 10.2 & 114.8 \\
\hline Female & 282 & 251 & 149 & 71 & 128 & 144 & 89 & 297 & 475 & 1134 & 801 & 259 & 4080 \\
\hline $\begin{array}{l}{ }^{*} \text { Mean } \\
\text { females }\end{array}$ & 15.7 & 13.9 & 8.3 & 3.9 & 7.1 & 8.0 & 4.9 & 16.5 & 26.4 & 63.0 & 44.5 & 14.4 & 226.7 \\
\hline Total & 397 & 391 & 195 & 99 & 168 & 205 & 138 & 439 & 718 & 1679 & 1275 & 443 & 6147 \\
\hline $\begin{array}{l}{ }^{*} \text { Mean } \\
\text { total }\end{array}$ & 22.1 & 21.7 & 10.9 & 5.5 & 9.3 & 11.4 & 7.7 & 24.4 & 39.9 & 93.3 & 70.8 & 24.6 & 341.5 \\
\hline $\begin{array}{l}\% \\
\text { collection }\end{array}$ & 6.5 & 6.4 & 3.2 & 1.6 & 2.7 & 3.3 & 2.2 & 7.1 & 11.7 & 27.3 & 20.7 & 7.2 & - \\
\hline Sex Ratio & $1: 2.5$ & $1: 1.8$ & $1: 3.2$ & $1: 2.5$ & $1: 3.2$ & $1: 2.4$ & $1: 1.8$ & $1: 2.1$ & $1: 2.1$ & $1: 2.1$ & $1: 1.7$ & $1: 1.4$ & $1: 2$ \\
\hline
\end{tabular}

${ }^{*}$ Mean: Number of RPW/trap (total 18 traps)

Effect of date fruit quantity on the number of RPW male caught in aggregation pheromone trap: The number of male weevils caught in pheromone traps varied significantly with date fruit quantity $(F=14.9, \mathrm{df}=2 ; \mathrm{p}<005)$. A total of 694,753 and 620 males were caught in traps containing 350 , 450 and $550 \mathrm{~g}$ of date fruit, respectively (Table 2). Traps with $450 \mathrm{~g}$ of date fruit recorded the highest yearly average of the three treatments, with 125.5 male weevils caught per trap while traps baited with $350 \mathrm{~g}$ had a yearly average of 115.7 male weevils, and those baited with $550 \mathrm{~g}$ had a yearly average of 103.3. Of the total number of weevils caught in traps, $33.6 \%$ were caught with $350 \mathrm{~g}, 36.4 \%$ were caught with $450 \mathrm{~g}$ and $30 \%$ were caught with $550 \mathrm{~g}$ of bait. Average monthly catch rates were 9.6, 10.5 and 8.6 male weevils per trap for these three treatments respectively. 
Agric. Biol. J. N. Am., 2013, 4(4): 496-503

Table 2. Effect of date's quantity on the numbers of RPW males caught in pheromone trapsin Al-Rahba, Abu Dhabi, UAE from June 1, 2010-May 31, 2011

\begin{tabular}{|l|c|c|c|c|}
\hline Treatment & $\begin{array}{c}\text { No. RPW male } \\
\text { caught/6 Traps/Year }\end{array}$ & Mean & \% collection & $\begin{array}{c}\text { Average monthly } \\
\text { number of weevils } \\
\text { caught per trap }\end{array}$ \\
\hline $\begin{array}{l}\text { Trap }+350 \mathrm{~g} \text { of } \\
\text { dates }\end{array}$ & 694 & $115.7 \mathrm{~b}$ & 33.6 & 9.6 \\
\hline $\begin{array}{l}\text { Trap }+450 \mathrm{~g} \text { of } \\
\text { dates }\end{array}$ & 753 & $125.5 \mathrm{a}$ & 36.4 & 10.5 \\
\hline $\begin{array}{l}\text { Trap }+550 \mathrm{~g} \text { of } \\
\text { dates }\end{array}$ & 620 & $103.3 \mathrm{c}$ & 30.0 & 8.6 \\
\hline Total & 2067 & 344.5 & 100 & 28.7 \\
\hline Mean & 689 & 114.8 & & 9.6 \\
\hline AVEDV & 46 & 7.7 & 2.2 & 0.6 \\
\hline STDEV & 66.6 & 11.1 & & \\
\hline SE \pm & & 2.6 & & \\
\hline CV $\%$ & & 9.7 & & \\
\hline LSD 5\% & & 9.1 & & \\
\hline
\end{tabular}

${ }^{*}$ Means with the same letter are not significantly different at $5 \%$ level of significance.

Effect of date palm fruits quantity on the number of RPW females caught in aggregation pheromone traps: We also found significant differences between treatments in the number of female weevils caught $(f=47.2, d f=2 ; p<0.005)$. A total of 1343,1477 and 1260 females were caught in traps baited with 350,450 and $550 \mathrm{~g}$ of date fruit respectively (Table 3). Traps containing $450 \mathrm{~g}$ of fruit had the highest yearly average catch of the three treatments, with 246.2 females caught per trap, followed by $350 \mathrm{~g}$ with 223.8 females caught per year on average, and $550 \mathrm{~g}$ with 210 females. Of the total number of female weevils caught, $32.9 \%$ were caught with $350 \mathrm{~g}, 36.2 \%$ were caught with $450 \mathrm{~g}$ and $30.9 \%$ were caught with $550 \mathrm{~g}$ of bait. Average monthly catch rates were 18.7, 20.5 and 17.5 female weevils per trap for these three treatments, respectively.

Table 3. Effect of date's quantity on the numbers of RPW female caught in pheromone traps in Al-Rahba, Abu Dhabi, UAEfrom June 1, 2010-May 31, 2011

\begin{tabular}{|l|c|c|c|c|}
\hline Treatment & $\begin{array}{c}\text { No. RPW female } \\
\text { caught /6 Traps /Year }\end{array}$ & Mean & \% collection & $\begin{array}{c}\text { Average monthly number } \\
\text { of weevils caught per trap }\end{array}$ \\
\hline Trap + 350 g of dates & 1343 & $223.8 \mathrm{~b}$ & 32.9 & 18.7 \\
\hline Trap + 450 g of dates & 1477 & $246.2 \mathrm{a}$ & 36.2 & 20.5 \\
\hline Trap + 550 g of dates & 1260 & $210.0 \mathrm{c}$ & 30.9 & 17.5 \\
\hline Total & 4080 & 680 & 100 & 56.7 \\
\hline Mean & 226.7 & 226.7 & & 18.9 \\
\hline AVEDV & 78 & 13 & 1.9 & \\
\hline STDEV & 109.5 & 18.2 & & \\
\hline SE \pm & & 4.3 & & \\
\hline CV $\%$ & 8 & & \\
\hline LSD 5\% & 8 & & \\
\hline
\end{tabular}

${ }^{*}$ Means with the same letter are not significantly different at $5 \%$ level of significance. 
Effect of date fruit quantity on the total number of RPW caught in aggregation pheromone trap: The results in table (4). Indicated that there were significant differences between the mean captured weevils of these three treatments $(f=42.4, \quad d f=2$; $\mathrm{p}<0.005)$. The total number of weevils caught were 2037, 2230 and 1880 for traps baited with, 350, 450 and $550 \mathrm{~g}$ of date fruits respectively. Traps baited with $450 \mathrm{~g}$ of date fruit caught the most weevils, with an average yearly catch (371.7) weevils per trap per year, followed by $350 \mathrm{~g}$ with 339.5 weevils caught per trap per year and $550 \mathrm{~g}$ with 313.3 weevils. Of the total number of weevils caught, $33.1 \%, 36.3 \%$ and $30.6 \%$ were caught with 350,450 and $550 \mathrm{~g}$ of date fruits respectively. The average monthly catch rates were 28.3, 31.0 and 26.1 weevils per trap per month for these three treatments respectively.

Table 4. Effect of dates quantity on the total numbers of RPW caught on pheromone trap in Al-Rahba, Abu Dhabi UAE during June 1, 2010-May 31, 2011

\begin{tabular}{|l|c|c|c|c|}
\hline Treatment & $\begin{array}{c}\text { No. total RPW caught/6 } \\
\text { Traps/Year }\end{array}$ & Mean & \% collection & $\begin{array}{c}\text { Average monthly } \\
\text { number of weevils } \\
\text { caught per trap }\end{array}$ \\
\hline Trap +350 g of dates & 2037 & $339.5 \mathrm{~b}$ & 33.1 & 28.3 \\
\hline Trap $+450 \mathrm{~g}$ of dates & 2230 & $371.7 \mathrm{a}$ & 36.3 & 31.0 \\
\hline Trap +550 g of dates & 1880 & $313.3 \mathrm{c}$ & 30.6 & 26.1 \\
\hline Total & 6147 & 1024.5 & 100 & 85.4 \\
\hline Mean & 2049 & 341.5 & & 28.5 \\
\hline AVEDV & 120.7 & 20.1 & 2.0 & 1.7 \\
\hline STDEV & 175.3 & 29.2 & & \\
\hline SE \pm & & 7 & & \\
\hline CV $\%$ & & 8.6 & & \\
\hline LSD 5\% & & 14 & & \\
\hline
\end{tabular}

${ }^{*}$ Means with the same letter are not significantly different at $5 \%$ level of significance

The pheromone traps used in this study revealed a population of RPW that, while presented year-round, fluctuated from month to month. Previous studies have found a similar pattern in weevil populations (Abraham et al, 1999; Al-Saoud 2009; Al-Saoud 2010; Vidyasagar et al, 2000a).

The number of weevils caught in traps was highest in March 2011 and lowest in September, 2010, and the seasonality of this population change corresponds with the findings of other studies (Abraham et al., 1999; Al-Saoud, 2004; Al-Saoud, 2009a; Al-Saoiud et al., 2010; Vidyasagar et al., 2000a). Abraham et al. (1999) found the period of highest weevil catch to be from April to November in 1995, but in 1996 recorded tow population peaks of activity- one from May to June and the other in October also in 1997 again recorded tow population peaks, this time in May and September. As noted in that study, our study and others, red palm weevil reproduction occurs all year and fluctuation in total captured numbers due to the climate change, making control of this pest difficult to achieve, the use of pesticides must be stopped especially using chemical pesticides must be applied from mid-January until the end of March (the pollination period), while no chemical pesticides use from the beginning of crop formation until the end of the maturing and harvesting of the crop due to the chemical pesticides residues in dates. The difficulty of chemical control of this pest makes the implementation and refinement of an effective Integrated Pest Management plan an important step in reducing its population.

We found the sex ratio of the red palm weevil caught in the pheromone traps to be 1:2 male: female overall, which differs from the results obtained by Abraham et al. (1999) from mid-1994 to December 
1994, who reported a sex ratio ranging from 1:2.35 to $1: 3.06$, with an overall average of 1:2.68 in favor of females. In other studies, (Al-Saoud, 2007; Al-Saoud, $2009 \mathrm{~b})$ reported a sex ratio ranging from $1: 1.33$ to 1:2.28, male: female.

We encountered one problem with the pheromone trap. Each trap had about 4-5 liter of water mixed with date fruit, but since the quantity of date fruit differed, the consistency of the resulting mixture also differed. The bait in traps with $550 \mathrm{~g}$ of dates was thicker than in traps with 350 or $450 \mathrm{~g}$, and water evaporation over the course of the week between surveys made each of these mixtures even thicker. By the end of the week, the mixture in traps baited with $550 \mathrm{~g}$ of date fruit had grown so thick it was difficult to move to stir in more water and suppress mold, Fungi, Algae and Mold all grew more quickly in traps baited with $550 \mathrm{~g}$ of date fruits compared with traps baited with 350 or $450 \mathrm{~g}$, and it could be that these factors had an impact on the effectiveness of theses traps.

Our results indicated $450 \mathrm{~g}$ of date fruit to be the most effective of the three quantities tested in attracting red palm weevils to the pheromone traps used in the United Arab Emirates to control this pest. To increase the number of weevils caught in these traps, it is important to maintain the traps regularly by adding new pheromone and changing the date fruit and water as need. Further study is needed to improve these techniques and optimize the use of these pheromone traps to enhance the management of this insect pest.

\section{ACKNOWLEDGEMENT}

We would like to acknowledge all colleagues at Banyans Research Station and Al-Rahba Extension Center for their help and support, particularly Mubarak Ali Al-Mansouri, Abdulmonem Al-Marshoudi and Ahmad Khaled Othman, Sameer Ali Al Dhalei, Ameen Nasser Al Wahedi.

\section{REFERENCES}

Abbas, M.S.T., Hanounik, S.B., Shahdad, A.S., and AlBagham, S.A. (2006). Aggregation-pheromone traps, a major component of IPM strategy for the red palm weevil, Rhynchophorus ferruginous (Coleoptera: Curculionidae) in date palms. Journal Pesticide Science. 79: 69-73.

Abdalah, F.F., and Al-Khatri, S.A. (2005). The effect of pheromone, kairomone and food bait on attracting adults of red palm weevil, Rhynchophorus ferruginous in the Sultanat Oman in date palm plantations. Paper presented at the $3^{\text {rd }}$ International Conference on IPM role in Integrated Crop Management and Impacts
Environment and Agricultural Products, November 2629, 2005, Geza, Egypt.

Abozuhairah, R.A.,Vidyasagar, P.S.P.V., and Abraham, V.A. (1996). Integrated management of red palm weevil, Rhynchophorus ferruginous $\mathrm{F}$., in date palm plantations of the Kingdom of Saudi Arabia. XX International Congress of Entomology, Firenze, Italy, August, 25-31. p. 541

Abraham, V.A., Al-Shuaibi, M.A., Faleiro, J.R., Abozuhairah, R.A., and Vidyasagar, P.S.P.V. (1998). An integrated Management approach for red palm weevil, Rhynchophorus ferrugineus Olivier-A key pest of date palm in the Middle East. Agricultural Sciences. 3: 77-83.

Abraham, V.A., Faleiro, J.R., Al-Shuaibi, M.A., and Prem Kumar, T. (2000). A strategy to manage red palm weevil Rhynchophorus ferruginousOliv.in date palm Phoenix dactylifera, its successful implementation in Al-Hassa, Kingdom of Saudi Arabia.Pestology. 24(12): 23-30.

Abraham, V.A., Faleiro, J.R., Nair, C.P.R., and Nair Saritha, S. (2002). Present management technologies for red palm weevil Rhynchophorus ferrugineus Olivier (Coleoptera:Cuculionidae) in palms and future thrust areas. Pest Management in Horticultural Ecosystems. 8(2): 69-82.

Abraham,V.A., Faleiro, J.R., Prem Kumar, T., and AlShuaibi, M.A. (1999). Sex ratio of red palm weevil Rhynchophorus ferrugineus Olivier captured from date plantation of Saudi Arabia using Pheromone traps. Indian Journal of Entomology. 61(2): 201-204.

Abraham,V.A., Faleiro, J.R., Al-Shuaibi, M.A and Abdan, S. (2001). Status of pheromone trap captured female red palm weevil from date gardens of Saudi Arabia. Journal of Tropical Agriculture. 39: 197-199.

Ajlan, A. (2009). The Red Palm Weevil. The Science Advisory Board.Access on Nov. 25, 2011 (http://www.scienceboard.net/community/perspectives.2 $\underline{\text { 39.html) }}$

Ajlan, A.M., and Abdulsalam, K.S. (2000). Efficiency of pheromone traps for controlling red palm weevil, Rhynchophorus ferrugineus (Olivier) (Coleoptera: Curculionidae), under Saudi Arabia conditions. Bulletin Entomological Society Egypt, Economic Serial. 27: 109120.

Al-Saoud, A. (2004). The role of Aggregation pheromone in Integrated Control of red palm weevil, Rhynchophorus ferrugineus Olivier (Coleoptera: Curculionidae) Pages 106-112 in: Proceedings of The Date Palm Regional Workshop on Ecosystem based IPM for Date Palm in the Gulf Countries UAE University, Al-Ain, UAE; 28-30 March 2004.

Al-Saoud, A. (2007). Importance of date fruit in red palm weevil, Rhynchophorus ferrugineus Olivier (Coleoptera: Curculionidae) aggregation pheromone traps. pp. 405- 
413. In: A. Zaid, V. Hegarty, H.H.S. Al Kaabi (Eds.) Proceeding of $3^{\text {th }}$ International Date Palm Conference, Abu Dhabi, United Arab Emirates. ISHS ActaHorticulturae 736.

Al-Saoud, A. (2009a). Effect of red palm weevil, Rhynchophorus ferruginous Olivier (Coleoptera: Curculionidae) aggregation pheromone traps contains on the number of capture weevils. Damascus University Journal for the Agricultural Sciences. 25(1): 151-175.

Al-Saoud, A. (2009b). The role of kairomone in red palm weevil, Rhynchophorus ferruginous Olivier (Coleoptera: Curculionidae) aggregation pheromone traps. Damascus University Journal for the Agricultural Sciences. 25(2): 125-144.

Al-Saoud, A. (2010a). Effect of red palm weevil, Rhynchophorus ferruginous Olivier (Coleoptera: Curculionidae) aggregation pheromone traps, height and colors on the number of captured weevils. pp 419429. In: A. Zaid and G.A. Alhadrami (Eds.) Proceeding of $4^{\text {th }}$ International Date Palm Conference, Abu Dhabi, United Arab Emirates. ISHS Acta Horticulturae 882.

Al-Saoud, A, (2010b). Investment Optimization of (RPW) Rhynchophorus ferrugineus (Coleoptera: Curculionidae) Aggregation Pheromone Traps in United Arab Emirates. Red Palm Weevil, the Challenge. 30-31 March 2010 Saudi Basic Industries Corporation (SABIC) Riyadh, Kingdom of Saudi Arabia.

Al-Saoud, A. (2011a). Comparative effectiveness of four food baits in aggregation pheromone traps on red palm weevil Rhynchophorus ferruginous Olivier. Arab Journal of Plant Protection. 29: 83-89.

Al-Saoud, A. (2011b). Effect of red palm weevil, Rhynchophorus ferrugineus Olivier (Coleoptera: Curculionidae) Aggregation Pheromone Traps Sites on the Number of Captured Weevils. Damascus University Journal for the Agricultural Sciences. 27(2): 77-97.

Al-Saoud, A. (2012). Effect of aggregation pheromone trap colors and kairomone in attracting adults of red palm weevil, Rhynchophorus ferrugineus Oliv. (Coleoptera: Curculionidae) in Al-Rahbba(Emirate of Abu Dhabi). Paper presented at $1^{\text {sT }}$ International Symposium on horticultural insects management 19-22 November, 2012. Amman-Jordan.

Al-Saoud, A., Al-Deeb, M. and Murchie, A.K. (2010). Effect of color on the trapping effectiveness of red palm weevil pheromone traps. Journal of Entomology 7(1): 54-59.

Bokhari, U.G., and Abozuhairah, R.A. (1992). Diagnostic tests for red palm weevil. Rhynchophorus ferrugineusinfested date palm trees. Arab Gulf Journal Science Research. 10(3): 93-104.

Faleiro, J.R. (2004). Pheromone based strategy for the management of red palm weevil in date palm and coconut agro-ecosystems: Implications, protocols and impact. Pages 44-52 in Proceedings of The Date Paper presented at Date Palm Regional Workshop on Ecosystem based IPM for Date Palm in the Gulf Countries UAE University, Al-Ain, UAE; 28-30 March 2004.

Faleiro, J.R. (2006). A review of the issues and management of the red palm weevil Rhynchophorus ferrugineus (Coleoptera: Rhynchophoridae) in coconut and date palm during the last one hundred years. International Journal Tropical Insect Science. 26(3): 135-154.

Faleiro, J.R., Abraham, V.A., and Al-Shuaibi, M.A. (1998). Role of pheromone trapping in the management of Red Palm Weevil. India Coconut Journal. 29(5): 1-3.

Faleiro, J.R., and Chellapan, Mani.(1999). Attraction of red palm weevil, Rhynchophorus ferrugineus Olivier to Ferrugineol based pheromone Lures in coconut gardens. Journal of Tropical Agriculture. 37: 60-63.

Faleiro, J.R., and Rangnekar, P.A. (2000). Sex ratio of pheromone trap captured red palm weevils, Rhynchophorus ferrugineus Olivier in coconut gardens of Goa. Presented at the International Conference on Plantation Crops (PLACROSYM XIV) Hyderabad, India, 12-15, December, 2000. Season IV Abstract 83.

Faleiro, J.R., and Rangnekar, P.A. (2001). Location specific seasonal activity of red palm weevil, Rhynchophorus ferrugineus Oliv. in Coconut plantations of Goa. Indian Journal of Applied Entomology. 15(2): 7- 15.

Faleiro, J.R., and Satarkar, V.R. (2003). Ferrugineol based pheromone Lures for trapping red palm weevil, Rhynchophorus ferrugineus (Coleoptera: Rhynchophoridae) in coconut plantations. Indian Journal plant Protection. 31(1): 84-87.

Ferry, M., and Gomez, S. (2002). The red palm weevil in the Mediterranean area. (formerly principles). The International Palm Society. 46: 172-178.

Frohlich, G., and Rodewald, W. (1970). Pests and diseases of tropical Crops and their Control.Pergamon Press, Oxford, UK. 371 p.

Hallett, R.H., Oehlschlager, A.C. and Broden, J.H. (1999). Pheromone trapping protocols for the Asian palm weevil, Rhynchophorus ferrugineus (Coleoptera: Curculionidae). International Journal of Pest Management. 45(30: 231-237.

Kaakeh, W. (2006). Toxicity of imidacloprid to development stages of Rhynchophorus ferrugineus Oliv. (Coleoptera: Curculionidae): Laboratory and field test. Crop Protection. 25: 432-439.

Murphy, S.T., and Briscoe, B.R. (1999). The red palm weevil as an alien invasive: biology and the prospects for biological control as a component of IPM. Biocontrol News and Information. 20(1): 35N-46N. 
Nair, S.S., Abraham, V.A., and Nair, C.P.R. (2000). Efficiency of different food baits in combination with pheromone lures in trapping adults of red weevil Rhynchophorus ferrugineus Oliv. (Coleoptera: Curculionidae). Pestology. 24(6): 3-5.

Oehlschlager, A.C. (1995). Rhynchophorus ferrugineus, a pest of date palm in the Middle East - current and future strategies for the management of weevil population. (based on experience of Central America with $R$. palmarum.). pp. 1-29. In: FAO. (1995): Report of the Expert Consultation on Date Palm-Pest Problems and their control in the Near East. (22-26 April, 1995); Al-Ain, United Arab Emirates.

Oehlschlager, A.C., (1998). Trapping of date palm weevil, In: Proceeding of an FAO workshop on date palm weevil (Rhynchophorus ferrugineus) and its control. 1517 December 1998, Cairo, Egypt.

Oehschlager, A.C., Chinchilla, C., Castillo, G., and Gonzalez, L.M. (2002). Control of red ring disease by mass trapping of Rhynchophorus palmarum (Coleoptera: Curculionidae), Florida Entomologist. 85: 507-513.
Poorjavad, N., Goldansaz, S. H., and Avand-Faghih, A. (2009). Response of the red palm weevil Rhynchophorus ferrugineus to its aggregation pheromone under laboratory conditions. Bulletin of Insectology. 62(2): 257-260.

Vidyasagar, P.S.P.V., AL-Saihati, A. A., Al-Mohanna, O.E., Subbei, A.I., and Abdul Mohsin, A.M. (2000a). Management of red palm weevil Rhynchophorus ferrugineus Oliv, a serious pest of date palm in Al-Qatif, Kingdom of Saudi Arabia.Journal of Plantation Crops. 28(1): 35-43.

Vidyasagar, P.S.P.V., Hagi, M., Abozuhairah, R.A., AlMohanna, O.E., and Al-Saihati, A.A. (2000b). Impact of mass pheromone trapping on red palm weevil: adult population and infestation level in date palm gardens of Saudi Arabia. Planter. 67 (891): 347-355.

Zohary, D., Hopf, M., and Weiss, E. (2012). Domestication of plants in the old world (4 $4_{\text {th }}$ Ed.). Oxford University Press. 264 p. 